\title{
Examination of Self-Confidence and Metacognition Levels of High School Students Case of Karabuk Province
}

\section{Huseyin Aslan ${ }^{1 \star}$ Musa Sahin ${ }^{2}$}

${ }^{1}$ Selçuk University, Sport Sciences Faculty, Konya, Turkey.

Email:husevinaslann6@omail.com Tel:+905373572588

${ }^{2}$ Karabük Üniversity, school of Physical Education and Sports, Karabük, Turkey.

Email:musasahin@karabuk.edu.trTel:05549755058

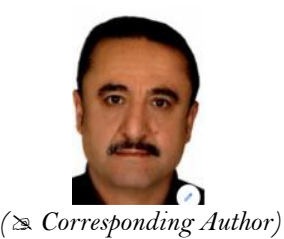

Corresponding Author)

\begin{abstract}
The aim of the study is to determine the relationship between self-confidence and metacognition of high school students and to contribute to the development of students. The study conducted in accordance with this purpose is correlational research. 420 students from different high schools participated in the study. $48.1 \%$ (202) of the students are female and $51.9 \%$ (218) are male. It consists of 7 different high schools where the students participated in the study and studied in the province of Karabük. The research findings were expressed as $n$, (\%), mean and standard deviation, and were considered significant at $\mathrm{p}<0.05$ significance level. All statistical calculations were made in SPSS 22.0 V. statistics package program. Considering all the findings and related researches obtained, it is seen that metacognitive skill plays an important role in students' success. In addition to this, it was observed that the success levels of students who developed the metacognitive strategy increased. In modeling, teachers can draw the attention of students to this area by presenting slices from their own lives and enable them to learn their skills in this area. Based on this, education that will improve students' metacognitive skills should be provided in all educational processes.
\end{abstract}

Keywords: Self-confidence, Metacognition, High school students, Education levels, Status, Gender variable.

Citation | Huseyin Aslan; Musa Sahin (2020). Examination of SelfConfidence and Metacognition Levels of High School Students Case of Karabuk Province. Asian Journal of Education and Training, 6(4): 608-615.

History:

Received: 17 September 2020

Revised: 2 October 2020

Accepted: 13 October 2020

Published: 27 October 2020

Licensed: This work is licensed under a Creative Commons

Attribution 3.0 License (cc)

Publisher: Asian Online Journal Publishing Group
Acknowledgement: Both authors contributed to the conception and design of the study.

Funding: This study received no specific financial support.

Competing Interests: The authors declare that they have no conflict of interests.

Transparency: The authors confirm that the manuscript is an honest, accurate, and transparent account of the study was reported; that no vital features of the study have been omitted; and that any discrepancies from the study as planned have been explained.

Ethical: This study follows all ethical practices during writing.

\section{Contents}

1. Introduction

2. Method

609

3. Results 


\section{Contribution of this paper to the literature}

The importance of metacognitive skills in students' success was stated. In addition, it was observed that the success levels of students who developed the metacognitive strategy increased. In modeling, teachers can draw the attention of students to this area by presenting sections from their own lives and enable them to learn their skills in this area.

\section{Introduction}

Self-confidence consists of two parts: internal and external confidence. Internal confidence is the individual's self-satisfaction, the feelings, and ideas that are tolerated and embraced by himself. Factors that reveal internal confidence are positive thinking and obvious goals such as self-esteem, self-love, self-awareness. External confidence, on the other hand, is the individual's attitudes and behaviors showed to his environment by him regarding he is satisfied and contented with himself. The factors that create external confidence are the ability to control their communication and feelings (Akagündüz, 2006). Self-confidence is the general feeling of the skill or competence of the individual to be successful (Michael \& Benjamin, 2004). Being in professions such as sports, music, painting, or speaking in front of the public requires a certain level of self-confidence (Bicer, 1997).

Individuals with low self-confidence see themselves as unsuccessful and worthless, no matter how successful they are according to objective evaluations (Wylie, 1961). These individuals believe that they lack the power to deal with their own issues in their daily lives and they are constantly worried about despair (Rogers \& Dymond, 1954). Individuals who consider themselves worthless are afraid to engage in love exchanges with the fear that their own inadequacies in intimate and open relationships will reveal and they will be rejected (From, 1947). Because they do not believe in their own values and judgments, they exhibit a life that is quickly affected, tends to change their beliefs and behaviors, and is dependent on others (Coopersmgth, 1967). With their characters which tend to all kinds of dependency, perversion, and committing crimes, they are dangerous for the society, besides obstructing their own development (Fitts, 1965).

High self-confidence is a necessary condition for attitudes that are considered harmonious, healthy, and normal according to the cultural context in which they live (Scott, 1968). Individuals that have high self-confidence, generally, have a characteristic feature that is open to new ideas/experiences and investigative (McGuire, 1968), open to new experiences and affectionate (From, 1947), and entrepreneurial and takes any responsibility (Fitch, 1970).

When individuals adopt an attitude in line with their self-concept, they feel safe and sufficient. When their attitudes are different from their self-evaluations and roles that they give for themselves, and they have difficulty adopting an attitude that is more different than they want, their self-confidence gets harmed (Kulaksızoğlu, 1999). Self-confidence can be defined as "boldness, courage" (Hambly, 1997).

Training efforts of conscious people in education continue to progress rapidly in a more meaningful way with the emergence of the concept of metacognition and studies on this subject. Metacognition, in its most detailed definition, is defined as being aware of and controlling mental activities involved in the individual's perception, remembering, and thinking (Huitt, 1997). The individual's knowledge of cognitive processes and products, and his awareness on this issue is called metacognition (Selcuk, 2000).

Metacognition is defined as follows: the ability to control and direct one's own cognitive processes according to Reeve and Brown (1985) a high degree of a managerial process using planning, monitoring, and evaluation to solve problems according to Sternberg (1988); understanding and controlling cognitive activity according to Shanahan (1992) understanding some factors that affect cognition, and monitoring and controlling cognition with small models according to Butterbield, Albertson, and Johnston (1995).

As Doğanay and Unal (2006) stated, individuals think by their nature. Thinking, metacognition, and learning are a constant state of transformation as different aspects of the same event. At this point, metacognition becomes an integral part of the thinking process.

Metacognition is both at the base of thinking and includes the whole of thinking skills. The abilities of a person to decide on the moves to apply while doing a job, to develop an attitude about that subject, to plan the job or subject in the mind, to control his plan continuously, to organize the wrong places in a continuous manner are included in the concept of metacognition. In this process, individuals gain better control over thinking and feeling by reflecting and evaluating their own thinking processes (Marzano et al., 1995).

Flavell was the first person to reveal the metacognition. To briefly explain the metacognition, it means that the individual is aware of his thinking processes and keeps these processes under control. Metacognition has been mostly studied by researchers working in the field of educational psychology after 1970. Flavell first explained the concept of metacognition in 1971 with the concept of "metamemory" for the purpose of storing, researching, perceiving, executing, and observing the content point of his memory. Metacognition has been defined as what is intentional, done consciously, foreseeing, what are done to achieve their goals. The concept of "cognition" was first used in this article by defining metacognition as monitoring and organization in the article published by Flavell (1976).

\section{Method}

\subsection{Model of the Study}

The aim of the study is to determine the relationship between self-confidence and metacognition of high school students and to contribute to the development of students. The study conducted in accordance with this purpose is correlational research. Correlated research methods allow explaining the connection and relationship between variables or to predict the results (Fraenkel, Wallen, \& Hyun, 2012).

\subsection{Participants}

420 students from different high schools participated in the study. $48.1 \%$ (202) of the students are female and $51.9 \%$ (218) are male. The high schools in which the students participated in the study and studied in Karabük province are 7 different high schools which are Karabük Demir Celik AHS (Anatolian High School), Cumhuriyet 
AHS, Kıymet Mustafa AHS, Karabuk 75. Yıl AHS, Zübeyde Hanım AHS, Yahya Kemal Beyatlı AHS, Karabük Industrial Vocational High School.

\subsubsection{Data Gathering Tools}

In the study, "self-confidence scale" and "metacognition scale" were used as data gathering tools. Information is given below according to data gathering tools:

\subsubsection{Self-Confidence Scale}

The self-confidence scale used to measure the self-confidence levels of students was developed by Akın (2007). The total number of items in the self-confidence scale is 33. The highest score that can be obtained from this 5grade likert type scale is 165 and the lowest score is 33. A high score from the scale which does not have negative items indicates a high level of self-confidence. Below 2.5 points on the self-confidence scale indicates low, 2.5 to 3.5 indicates medium, and 3.5 and above indicates high self-confidence. Other items were named as $2,6,8,11,13,14$, $16,18,20,22,24,26,28,29,31,33$; they are related to the self-confidence of individuals towards their external environment and social life, and they include features such as the ability of individuals to communicate easily, to express themselves in a healthy way, to control their emotions and to take risks.

\subsubsection{Metacognition Scale}

Metacognition Questionnaire-30 was used to determine the metacognitive levels of the students in the study. The original name of the scale developed by Cartwright-Hatton and Wells (1997) is the "Meta-Cognitions Questionnaire (MCQ)". Translation of the scale into Turkish, validity, and reliability studies were carried out by Tosun and Irak (2008). Each item in the MCQ-30 is answered on a 4-unit Likert-type grading scale, with "(1) strongly disagree" and "(4) strongly agree" ends. The scores that can be obtained from the scale range from 30 to 120 and a higher score indicates an increase in pathological metacognitive activity.

\subsection{Statistical Analysis of Data}

Shapiro-Wilk normality test was applied to check whether the error terms showed normal distribution before the selection of the tests to be applied to the data obtained in the study $(\mathrm{P}>0.05)$. Independent-Samples test, oneway analysis of variance (One-way ANOVA) and Tukey HSD multiple comparison test were used for the total scores obtained from each scale and sub-dimensions of the scale. Relationships between self-confidence and the metacognitive scale and the total scores obtained from the sub-dimensions of the scale were analyzed with the Pearson correlation coefficient. The research findings were expressed as $\mathrm{n},(\%)$, mean and standard deviation, and were considered significant at $\mathrm{P}<0.05$ significance level. All statistical calculations were made in SPSS 22.0 V. statistics package program. The repetitive Cronbach Alpa of the self-confidence scale was found to be 0.91 , and the Metacognitive Scale to be 0.76 .

\section{Results}

Table-1. Demographic characteristics of participants.

\begin{tabular}{|c|c|c|c|}
\hline Variables & Variables & $\mathbf{N}$ & $\%$ \\
\hline \multirow{3}{*}{ Gender } & Female & 202 & 48.1 \\
\hline & Male & 218 & 51.9 \\
\hline & Total & 420 & 100.0 \\
\hline \multirow{8}{*}{ High School where the participant is educated } & Karabük Demir Çelik AHS & 60 & 14.3 \\
\hline & Cumhuriyet AHS & 60 & 14.3 \\
\hline & Kıymet Mustafa AHS & 60 & 14.3 \\
\hline & Karabuk 75. Yıl AHS & 60 & 14.3 \\
\hline & Zübeyde Hanım AHS & 60 & 14.3 \\
\hline & Yahya Kemal Beyatlı AHS & 60 & 14.3 \\
\hline & Karabük Industrial Vocational High School & 60 & 14.3 \\
\hline & Total & 420 & 100.0 \\
\hline \multirow{3}{*}{ Grade } & 11 th Grade & 210 & 50.0 \\
\hline & 12th Grade & 210 & 50.0 \\
\hline & Total & 420 & 100.0 \\
\hline \multirow{7}{*}{ Mother's Educational Status } & Elementary school & 152 & 36.2 \\
\hline & Secondary school & 125 & 29.8 \\
\hline & High School & 96 & 22.9 \\
\hline & Associate Degree & 24 & 5.7 \\
\hline & Undergraduate & 17 & 4.0 \\
\hline & Graduate & 6 & 1.4 \\
\hline & Total & 420 & 100.0 \\
\hline \multirow{7}{*}{ Father's Educational Status } & Elementary school & 76 & 18.1 \\
\hline & Secondary school & 127 & 30.2 \\
\hline & High School & 145 & 34.5 \\
\hline & Associate Degree & 31 & 7.4 \\
\hline & Undergraduate & 31 & 7.4 \\
\hline & Graduate & 10 & 2.4 \\
\hline & Total & 420 & 100.0 \\
\hline \multirow{5}{*}{ Place where the participant grew up } & Metropolitan & 34 & 8.1 \\
\hline & Province & 297 & 70.7 \\
\hline & District & 66 & 15.7 \\
\hline & Village-Town & 23 & 5.5 \\
\hline & Total & 420 & 100.0 \\
\hline
\end{tabular}

Note: ${ }^{*} \mathrm{p}<0.05$ 
Table-2. Self-confidence levels of the participants according to gender variable

\begin{tabular}{c|c|c|c|c|c|c}
\hline Sub-dimensions & Gender & $\mathbf{n}$ & Mean & S.d. & t & p-value \\
\hline \multirow{2}{*}{ Internal self-confidence } & Male & 202 & 58.82 & 10.36 & \multirow{2}{*}{0.746} & \multirow{2}{*}{0.456} \\
\cline { 2 - 7 } & Female & 217 & 58.07 & 10.15 & & \multirow{2}{*}{0.934} \\
\hline \multirow{2}{*}{ External self-confidence } & Male & 202 & 59.50 & 10.10 & \\
\cline { 2 - 6 } & Female & 217 & 58.55 & 10.05 & & \\
\hline
\end{tabular}

In the study, according to Table 2 , the self-confidence scale, and total scores of the sub-dimensions of the scale do not show a statistically significant difference $(\mathrm{p}>0.05)$.

Table-3. Self-confidence levels of the participants according to the variable of high school where they are educated.

\begin{tabular}{|c|c|c|c|c|c|c|c|}
\hline $\begin{array}{l}\text { Sub- } \\
\text { dimensions }\end{array}$ & $\begin{array}{l}\text { High School where the participant } \\
\text { is educated }\end{array}$ & $\mathbf{n}$ & Mean & S.d. & $\mathbf{F}$ & p-value & Difference \\
\hline \multirow{7}{*}{$\begin{array}{l}\text { Internal self- } \\
\text { confidence }\end{array}$} & 1- Karabük Demir Çelik AHS & 60 & 59.95 & 12.92 & \multirow{7}{*}{2.147} & \multirow{7}{*}{0.047} & \multirow{7}{*}{$\begin{array}{l}1-6 \\
2-6 \\
4-6 \\
5-6 \\
7-6\end{array}$} \\
\hline & 2- Cumhuriyet AHS & 60 & 59.75 & 4.42 & & & \\
\hline & 3- Kiymet Mustafa AHS & 60 & 57.53 & 9.62 & & & \\
\hline & 4- Karabuk 75. Yil AHS & 60 & 59.57 & 8.13 & & & \\
\hline & 5-Zübeyde Hanım AHS & 60 & 58.35 & 12.57 & & & \\
\hline & 6- Yahya Kemal Beyatlı AHS & 60 & 54.53 & 11.43 & & & \\
\hline & $\begin{array}{lll}7- & \text { Karabük } & \text { Industrial } \\
\text { High School } & & \\
\end{array}$ & 60 & 59.36 & 9.45 & & & \\
\hline \multirow{7}{*}{$\begin{array}{l}\text { External self- } \\
\text { confidence }\end{array}$} & 1- Karabük Demir Çelik AHS & 60 & 61.81 & 11.42 & \multirow{7}{*}{3.734} & \multirow{7}{*}{0.001} & \multirow{7}{*}{$\begin{array}{l}1-6 \\
2-6 \\
4-6 \\
7-6\end{array}$} \\
\hline & 2- Cumhuriyet AHS & 60 & 60.13 & 4.54 & & & \\
\hline & 3- Kiymet Mustafa AHS & 60 & 57.53 & 9.45 & & & \\
\hline & 4- Karabuk 75. Yil AHS & 60 & 60.22 & 9.67 & & & \\
\hline & 5-Zübeyde Hanım AHS & 60 & 58.05 & 12.53 & & & \\
\hline & 6- Yahya Kemal Beyatlı AHS & 60 & 54.58 & 10.93 & & & \\
\hline & $\begin{array}{lll}7-\quad \text { Karabük } & \text { Industrial } & \text { Vocational } \\
\text { High School } & & \end{array}$ & 60 & 60.80 & 8.52 & & & \\
\hline
\end{tabular}

Note: ${ }^{*} \mathrm{p}<0.05$

When Table 3 is examined, statistical significances were found in the self-confidence scale and sub-dimensions of the scale according to the high schools where the participants were educated $(p<0.05)$. Yahya Kemal Beyatl High School students' self-confidence levels scores are lower than other high schools.

Table-4. Self-confidence levels of the participants according to mother's educational status

\begin{tabular}{|c|c|c|c|c|c|c|c|}
\hline Sub-dimensions & Mother's Educational Status & $\bar{n}$ & Mean & S.d. & $\mathbf{F}$ & p-value & Difference \\
\hline \multirow{6}{*}{ Internal self-confidence } & 1- Elementary school & 152 & 57.50 & 8.87 & \multirow{6}{*}{1.683} & \multirow{6}{*}{0.137} & \\
\hline & 2- Secondary school & 124 & 59.43 & 9.90 & & & \\
\hline & 3- High school & 96 & 57.56 & 12.29 & & & \\
\hline & 4- Associate degree & 24 & 62.75 & 11.19 & & & \\
\hline & 5- Undergraduate & 17 & 59.65 & 8.78 & & & \\
\hline & 6- Graduate & 6 & 54.83 & 11.72 & & & \\
\hline \multirow{6}{*}{ External self-confidence } & 1- Elementary school & 152 & 57.39 & 9.03 & \multirow{6}{*}{3.530} & \multirow{6}{*}{0.004} & \multirow{6}{*}{$\begin{array}{l}1-4 \\
2-4 \\
3-4\end{array}$} \\
\hline & 2- Secondary school & 124 & 59.15 & 9.27 & & & \\
\hline & 3- High school & 96 & 58.99 & 12.15 & & & \\
\hline & 4- Associate degree & 24 & 65.88 & 10.00 & & & \\
\hline & 5- Undergraduate & 17 & 62.24 & 6.33 & & & \\
\hline & 6- Graduate & 6 & 61.33 & 13.05 & & & \\
\hline
\end{tabular}

Note: $* \mathrm{p}<0.05$

When Table 4 is examined in the study, the "external confidence", which is a sub-dimension of the selfconfidence scale, differs statistically $(\mathrm{p}<0.05)$. The mean score of the participants whose mother educational status is associate degree was found to be higher than primary school, middle school, and high school. No statistical significance was found in the internal self-confidence which is the other sub-dimension of the self-confidence scale $(\mathrm{p}>0.05)$.

Table -5. Self-confidence levels of the participants according to father's educational status

\begin{tabular}{|c|c|c|c|c|c|c|c|}
\hline Sub-dimensions & Father's Educational Status & $\bar{n}$ & Mean & S.d. & $\mathbf{F}$ & p-value & Difference \\
\hline \multirow{6}{*}{$\begin{array}{l}\text { Internal self- } \\
\text { confidence }\end{array}$} & 1- Elementary school & 76 & 56.24 & 11.31 & \multirow{6}{*}{1.079} & \multirow{6}{*}{0.371} & \\
\hline & 2- Secondary school & 126 & 58.29 & 9.63 & & & \\
\hline & 3- High school & 145 & 59.23 & 10.59 & & & \\
\hline & 4- Associate degree & 31 & 60.23 & 10.02 & & & \\
\hline & 5- Undergraduate & 31 & 58.68 & 8.97 & & & \\
\hline & 6- Graduate & 10 & 59.00 & 8.38 & & & \\
\hline \multirow{6}{*}{$\begin{array}{l}\text { External self- } \\
\text { confidence }\end{array}$} & 1- Elementary school & 76 & 56.43 & 10.59 & \multirow{6}{*}{2.287} & \multirow{6}{*}{0.045} & \multirow{6}{*}{$\begin{array}{l}1-3 \\
1-4\end{array}$} \\
\hline & 2- Secondary school & 126 & 58.10 & 9.92 & & & \\
\hline & 3- High school & 145 & 60.17 & 10.25 & & & \\
\hline & 4- Associate degree & 31 & 61.90 & 7.76 & & & \\
\hline & 5- Undergraduate & 31 & 60.13 & 9.73 & & & \\
\hline & 6- Graduate & 10 & 61.10 & 9.46 & & & \\
\hline
\end{tabular}

Note: $* \mathrm{p}>0.05$ 
When Table 5 is examined, a statistical difference was found in the "external confidence" which is a subdimension of the self-confidence scale $(\mathrm{p}<0.05)$. According to the data obtained, the mean scores of external selfconfidence of the participants whose father's educational status was the associate degree was found to be higher than their other educational status. No statistical significance was found in the internal confidence sub-dimension $(\mathrm{p}>0.05)$.

Table-6. Self-confidence levels according to the variable of place where the participant grew up.

\begin{tabular}{|c|c|c|c|c|c|c|}
\hline Sub-dimensions & Place where the participants grew up & $\mathbf{n}$ & Mean & S.d. & $\mathbf{F}$ & p-value \\
\hline \multirow{4}{*}{ Internal self-confidence } & Metropolitan & 34 & 60.12 & 8.15 & \multirow{4}{*}{0.406} & \multirow{4}{*}{0.749} \\
\hline & Province & 296 & 58.16 & 10.45 & & \\
\hline & District & 66 & 58.82 & 8.81 & & \\
\hline & Village-Town & 23 & 58.39 & 14.07 & & \\
\hline \multirow{4}{*}{ External self-confidence } & Metropolitan & 34 & 61.38 & 7.11 & \multirow{4}{*}{0.833} & \multirow{4}{*}{0.476} \\
\hline & Province & 296 & 58.64 & 10.59 & & \\
\hline & District & 66 & 59.20 & 8.37 & & \\
\hline & Village-Town & 23 & 59.91 & 11.37 & & \\
\hline
\end{tabular}

Note: ${ }^{*} \mathrm{p}>0.05$.

When Table 6 was examined in our study, no statistical significance was found between the self-confidence scale and sub-dimension scores of the scale according to the variable of place where the participants grew up ( $\mathrm{P}>$ 0.05).

Table-7. Metacognitive levels of the participants according to gender variable

\begin{tabular}{|c|c|c|c|c|c|c|}
\hline Sub-dimensions & Gender & n & Mean & S.d. & $\mathbf{t}$ & p-value \\
\hline \multirow{2}{*}{ Positive meta-worries } & Male & 202 & 13.43 & 4.26 & \multirow{2}{*}{0.260} & \multirow{2}{*}{0.795} \\
\hline & Female & 218 & 13.33 & 3.63 & & \\
\hline \multirow{2}{*}{ Negative meta-worries } & Male & 202 & 16.08 & 3.50 & \multirow{2}{*}{0.144} & \multirow{2}{*}{0.886} \\
\hline & Female & 218 & 16.13 & 3.48 & & \\
\hline \multirow{2}{*}{ Superstitions } & Male & 202 & 16.12 & 3.27 & \multirow{2}{*}{0.672} & \multirow{2}{*}{0.502} \\
\hline & Female & 218 & 15.91 & 3.16 & & \\
\hline \multirow{2}{*}{ Cognitive monitoring } & Male & 202 & 17.21 & 3.47 & \multirow{2}{*}{0.008} & \multirow{2}{*}{0.994} \\
\hline & Female & 218 & 17.22 & 3.93 & & \\
\hline
\end{tabular}

Note: $* \mathrm{p}>0.05$

When Table 7 is examined, no statistical significance was determined in the mean scores of the participants' metacognitive levels and sub-dimensions $(\mathrm{p}>0.05)$.

Table-8. Metacognitive levels of the participants according to variable of high school where they are educated.

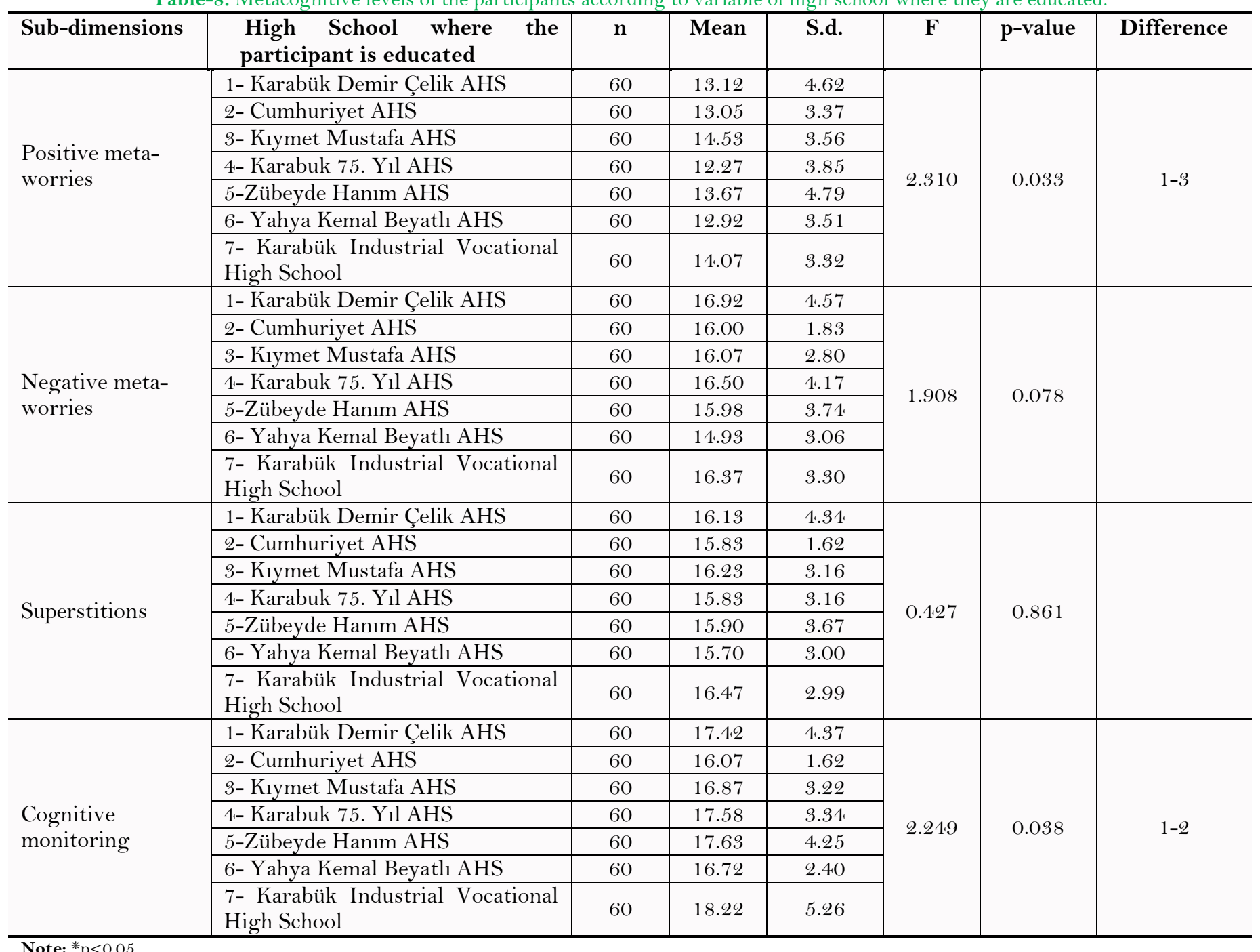


When Table 8 is examined in our study, according to the high school variable of the participants, "positive meta-worries and cognitive monitoring" sub-dimensions from the metacognitive scale and the sub-dimensions of the scale, show statistical significance $(\mathrm{p}<0.05)$. No statistical difference was found in the negative meta-worries and superstitions sub-dimensions $(\mathrm{p}>0.05)$.

Table-9. Metacognitive levels of the participants according to the variable of mother's educational status.

\begin{tabular}{|c|c|c|c|c|c|c|}
\hline Sub-dimensions & Mother's Educational Status & $\mathbf{n}$ & Mean & S.d. & $\mathbf{F}$ & p-value \\
\hline \multirow{6}{*}{ Positive meta-worries } & 1- Elementary school & 152 & 13.42 & 3.81 & \multirow{6}{*}{1.449} & \multirow{6}{*}{0.206} \\
\hline & 2- Secondary school & 125 & 13.07 & 3.83 & & \\
\hline & 3- High school & 96 & 13.49 & 4.33 & & \\
\hline & 4- Associate degree & 24 & 14.58 & 4.10 & & \\
\hline & 5- Undergraduate & 17 & 12.00 & 3.06 & & \\
\hline & 6- Graduate & 6 & 15.67 & 3.14 & & \\
\hline \multirow{6}{*}{ Negative meta-worries } & 1- Elementary school & 152 & 15.75 & 3.43 & \multirow{6}{*}{0.938} & \multirow{6}{*}{0.456} \\
\hline & 2- Secondary school & 125 & 16.07 & 3.77 & & \\
\hline & 3- High school & 96 & 16.43 & 3.10 & & \\
\hline & 4- Associate degree & 24 & 16.42 & 3.59 & & \\
\hline & 5- Undergraduate & 17 & 16.76 & 3.65 & & \\
\hline & 6- Graduate & 6 & 17.83 & 3.43 & & \\
\hline \multirow{6}{*}{ Superstitions } & 1- Elementary school & 152 & 15.81 & 2.99 & \multirow{6}{*}{0.801} & \multirow{6}{*}{0.550} \\
\hline & 2- Secondary school & 125 & 16.13 & 3.26 & & \\
\hline & 3- High school & 96 & 16.11 & 3.55 & & \\
\hline & 4- Associate degree & 24 & 16.96 & 3.33 & & \\
\hline & 5- Undergraduate & 17 & 15.24 & 2.68 & & \\
\hline & 6- Graduate & 6 & 15.67 & 3.20 & & \\
\hline \multirow{6}{*}{ Cognitive monitoring } & 1- Elementary school & 152 & 16.99 & 4.15 & \multirow{6}{*}{0.810} & \multirow{6}{*}{0.543} \\
\hline & 2- Secondary school & 125 & 17.37 & 3.43 & & \\
\hline & 3- High school & 96 & 17.34 & 3.30 & & \\
\hline & 4- Associate degree & 24 & 18.21 & 3.49 & & \\
\hline & 5- Undergraduate & 17 & 16.41 & 3.68 & & \\
\hline & 6- Graduate & 6 & 16.00 & 5.06 & & \\
\hline
\end{tabular}

When Table 9 is examined in the study, the sub-dimensions of the metacognitive scale of the mother's educational level variable do not differ statistically $(p>0.05)$.

Table -10. Metacognitive levels of the participants according to fathers' educational level.

\begin{tabular}{|c|c|c|c|c|c|c|}
\hline Sub-dimensions & Mother's Educational Status & $\mathbf{n}$ & Mean & S.d. & $\mathbf{F}$ & p-value \\
\hline \multirow{6}{*}{ Positive meta-worries } & 1- Elementary school & 76 & 14.13 & 3.76 & \multirow{6}{*}{1.805} & \multirow{6}{*}{0.111} \\
\hline & 2- Secondary school & 127 & 13.39 & 3.85 & & \\
\hline & 3- High school & 145 & 12.73 & 3.98 & & \\
\hline & 4- Associate degree & 31 & 14.29 & 4.63 & & \\
\hline & 5- Undergraduate & 31 & 13.26 & 3.57 & & \\
\hline & 6- Graduate & 10 & 14.30 & 3.74 & & \\
\hline \multirow{6}{*}{ Negative meta-worries } & 1- Elementary school & 76 & 16.28 & 3.30 & \multirow{6}{*}{0.508} & \multirow{6}{*}{0.770} \\
\hline & 2- Secondary school & 127 & 15.90 & 3.43 & & \\
\hline & 3- High school & 145 & 15.95 & 3.73 & & \\
\hline & 4- Associate degree & 31 & 16.71 & 3.23 & & \\
\hline & 5- Undergraduate & 31 & 16.58 & 3.18 & & \\
\hline & 6- Graduate & 10 & 16.50 & 3.84 & & \\
\hline \multirow{6}{*}{ Superstitions } & 1- Elementary school & 76 & 15.96 & 3.34 & \multirow{6}{*}{0.500} & \multirow{6}{*}{0.776} \\
\hline & 2- Secondary school & 127 & 15.91 & 3.04 & & \\
\hline & 3- High school & 145 & 16.18 & 3.31 & & \\
\hline & 4-Associate degree & 31 & 16.52 & 3.24 & & \\
\hline & 5- Undergraduate & 31 & 15.58 & 3.44 & & \\
\hline & 6- Graduate & 10 & 15.20 & 2.44 & & \\
\hline \multirow{6}{*}{ Cognitive monitoring } & 1- Elementary school & 76 & 16.89 & 5.05 & \multirow{6}{*}{0.696} & \multirow{6}{*}{0.626} \\
\hline & 2- Secondary school & 127 & 17.28 & 3.20 & & \\
\hline & 3- High school & 145 & 16.99 & 3.55 & & \\
\hline & 4- Associate degree & 31 & 17.84 & 3.25 & & \\
\hline & 5- Undergraduate & 31 & 17.81 & 3.12 & & \\
\hline & 6- Graduate & 10 & 18.20 & 3.39 & & \\
\hline
\end{tabular}

Note: $* \mathrm{p}>0.05$

When Table 10 is examined, the sub-dimensions of the metacognitive scale of father's educational status variable do not show statistical significance $(\mathrm{p}>0.05)$.

When Table 11 was examined, no statistically difference was found in the sub-dimensions of the metacognitive scale of the variable of the place where the participants grew up ( $>0.05)$. 
Table -11. Metacognitive levels of the participants according to the variable of the place where they grew up.

\begin{tabular}{|c|c|c|c|c|c|c|}
\hline Sub-dimensions & Mother's Educational Status & $\mathbf{n}$ & Mean & S.d. & $\mathbf{F}$ & p-value \\
\hline \multirow{4}{*}{ Positive meta-worries } & 1- Metropolitan & 34 & 13.09 & 3.55 & \multirow{4}{*}{0.093} & \multirow{4}{*}{0.093} \\
\hline & 2- Province & 297 & 13.43 & 3.91 & & \\
\hline & 3- District & 66 & 13.30 & 4.17 & & \\
\hline & 4- Village-Town & 23 & 13.26 & 4.35 & & \\
\hline \multirow{4}{*}{ Negative meta-worries } & 1- Metropolitan & 34 & 15.53 & 4.04 & \multirow{4}{*}{0.490} & \multirow{4}{*}{0.690} \\
\hline & 2- Province & 297 & 16.22 & 3.38 & & \\
\hline & 3- District & 66 & 15.91 & 3.27 & & \\
\hline & 4- Village-Town & 23 & 16.09 & 4.51 & & \\
\hline \multirow{4}{*}{ Superstitions } & 1- Metropolitan & 34 & 15.82 & 3.61 & \multirow{4}{*}{0.149} & \multirow{4}{*}{0.930} \\
\hline & 2- Province & 297 & 16.01 & 3.12 & & \\
\hline & 3-District & 66 & 16.21 & 3.09 & & \\
\hline & 4- Village-Town & 23 & 15.83 & 4.22 & & \\
\hline \multirow{4}{*}{ Cognitive monitoring } & 1- Metropolitan & 34 & 16.88 & 3.71 & \multirow{4}{*}{0.241} & \multirow{4}{*}{0.867} \\
\hline & 2-Province & 297 & 17.24 & 3.82 & & \\
\hline & 3-District & 66 & 17.11 & 3.08 & & \\
\hline & 4- Village-Town & 23 & 17.70 & 4.06 & & \\
\hline
\end{tabular}

Note: ${ }^{*} \mathrm{p}>0.05$.

Table -12. The relationship between the self-confidence scale and metacognitive scale scores of the participants

\begin{tabular}{c|c|c|c|c|c}
\hline Sub-dimensions & Values & $\begin{array}{c}\text { Positive } \\
\text { meta-worries }\end{array}$ & $\begin{array}{c}\text { Negative meta- } \\
\text { worries }\end{array}$ & Superstitions & $\begin{array}{c}\text { Cognitive } \\
\text { monitoring }\end{array}$ \\
\hline \multirow{2}{*}{ Internal self-confidence } & $\mathrm{r}$ & -.082 & -.069 & -.044 &, $125^{*}$ \\
\cline { 2 - 6 } & $\mathrm{p}$-value &, 093 &, 159 &, 368 &, 010 \\
\hline \multirow{2}{*}{ External self-confidence } & $\mathrm{r}$ & -.054 & -.074 & -.036 &, $104^{*}$ \\
\cline { 2 - 6 } & $\mathrm{p}$-value &, 272 &, 132 &, 459 &, 033 \\
\hline Note: $* \mathrm{p}<0.05$
\end{tabular}

As can be understood from Table 11 a statistically positive significant relationship was found between the internal self-confidence and external self-confidence scores, which are the sub-dimensions of the self-confidence scale, and the cognitive monitoring sub-dimension, which is one of the sub-dimensions of the metacognitive scale ( $\mathrm{p}$ $<0.05)$.

\section{Discussion Conclusion}

As a result of the analysis, according to Table 2, the self-confidence levels of the participants according to the gender variable do not show a statistically significant difference. In a study conducted by Bostancı, Ozen, Yıldız, and Uzüm (2016) in the self-confidence levels of students were examined and found results that support our study. It was emphasized that students' gender variables did not make any difference in terms of self-confidence perception scores

When the metacognitive levels of the participants according to the gender variable are examined in Table 7, no statistical significance could be determined. In a study conducted by Spence, Yore, and Williams (1999) it was emphasized that there was not statistically difference between the metacognitive levels of male and female students. This study also supports our study. In the studies conducted, it was observed that female students' metacognitive levels had statistically higher scores than male students and a significant difference was observed.

When Table 8 is examined in our study, according to the high school variable of the participants, "positive meta-worries and cognitive monitoring" sub-dimensions from the metacognitive scale and the sub-dimensions of the scale, show statistical significance. Considering this result, the analysis results of the 2nd and 3rd study questions in the study conducted by Akalin (2008) showed that there was a statistically significant difference between the average scores of male and female students on the metacognitive efficiency scale according to their grades in favor of the 2nd, 3rd and 4th grades for both girls and boys. In the 4th, 5 th, 6 th, and 7 th questions of the study, it was not revealed that there was no statistically significant difference between the average scores of male and female students at the same level from the metacognitive activity scale.

When Table 9 is examined in the study, the sub-dimensions of the metacognitive scale of the mother's educational status variable do not differ statistically. In the study conducted by Demir and Ozmen (2011) when the education levels and professions of the mothers are taken into account, a significant difference is observed in the total uncontrollability and danger, cognitive awareness and metacognition; according to the mother's educational level; according to the mother's profession, there is a significant difference in the sub-dimension of need for thought control. It is observed that students whose mothers were university graduates revealed a significant difference in both uncontrollability and danger, cognitive awareness total scores, and metacognition total scores.

Considering all the findings and related researches obtained, it is seen that metacognitive skill plays an important role in students' success. In addition to this, it was observed that the success levels of students who developed the metacognitive strategy increased. In modeling, teachers can draw the attention of students to this area by presenting slices from their own lives and enable them to learn their skills in this area. Based on this, education that will improve students' metacognitive skills should be provided in all educational processes. Having students' self-confidence positively affects their beliefs that they will do any activity more successfully. It should not be forgotten that individuals with high self-confidence have high levels of success and they are at peace with themselves.

\section{References}

Akagündüz, N. (2006). Self-confidence concept in human life. Istanbul: Umraniye Guidance and Research Center Directorate Publications. Akalin, K. H. (2008). The motivation of slection and the sense of individual responsibility in religious rationalists. Bolu Abant Izzet Baysal University Journal of Social Sciences Institute, 2(17), 1-18. 
Akın, A. (2007). Development and psychometric properties of self-confidence scale, Abü. Journal of Faculty of Education, 7(2), 165-175.

Bicer, T. (1997). Top performance in life and sports (pp. 136-145). Istanbul: Sistem Publishing.

Bostancı, T. G., Ozen, G., Yıldız, N. O., \& Uzüm, H. (2016). Studyzng self-confidence perception of school of education and sports students in terms of different varzables. Paper presented at the The 10th International Conference In Physical Education, Sports And Physical Therapy, November 18-20, Firat University, Elazig, Turkey.

Butterbield, E. C., Albertson, L. R., \& Johnston, J. C. (1995). On making cognitive theory more general and developmentally pertinent. In F. E. Weinert, W. Schneider (Eds.). Memory performance and competencies: Issues in growth and development. Mahwah, NJ: Lawrence Erbaum.

Cartwright-Hatton, S., \& Wells, A. (1997). Beliefs about worry and intrusions: The meta-cognitions questionnaire and its correlates. Journal of Anxiety Disorders, 11 (3), 279-296. Available at: https://doi.org/10.1016/s0887-6185(97)00011-x.

Coopersmġth, S. (1967). The antecedents of self-esteem. San Francisco: Freeman.

Demir, Ö., \& Ozmen, S. K. (2011). An investigation of University students' metacognition levels in terms of various variables, Ç.Ü. Journal of Social Sciences Institute, 20(3), 145-160.

Doğanay, A., \& Unal, F. (2006). Teaching of critical thinking”, A. Şimşek (Editor), Education based on content types (pp. 207-264). Ankara: Nobel Yayınları.

Fitch, G. (1970). Effects of self-esteem, perceived performance, and choice on causal attributions. Journal of Personality and Social Psychology, 16(2), 31 1-315. Available at: https://doi.org/10.1037/ho029847.

Fitts, W. (1965). The self concept and performance. Nashville, Tenn: Counseler Recordings and Tests.

Flavell, J. H. (1976). Metacognitive aspects of problem solving. Hillsdale: The Nature of İntelligence.

Fraenkel, J. R., Wallen, N. E., \& Hyun, H. H. (2012). How to design and evaluate research in education (8th ed.). New York: McGram-Hill Companies.

From, H. (1947). Man For himself. New-York: Reinehart.

Hambly, K. (1997). Self-confidence, translation: Baris Bicakci. Istanbul: Route Publications.

Huitt, W. (1997). Metacognition. Educational psychology interactive. Valdosta, GA: Valdosta State University.

Kulaksizoğlu, A. (1999). Adolescent psychology (2nd ed.). Istanbul: Remzi Publishing House.

Marzano, R. J., Brandt, R. S., Hughes, C. S., Jones, B. F., Rankin, S. C., \& Suhor, C. (1995). Dimensions of thinking: A model for curriculum and instruction (A. Doğanay \& Kara Z., Trans.). Cukurova University Journal of Education Faculty, 1(1 1), 25-38.

McGuire, W. J. (1968). Personality and susceptibility to social influence. In E.F. Borgatta \& W.W. Lambert (Eds.), Handbook of personality theory and research (pp. 1130-1187). Chicago: Rand-McNally.

Michael, M. J., \& Benjamin, C. P. (2004). Psychological skills training in sport. Denton, Texas, USA: University of North Texas.

Reeve, R. A., \& Brown, A. L. (1985). Metacognition reconsidered: Implications for intervention research. Journal of Abnormal Child Psychology, 13(3), 343-356. Available at: https://doi.org/10.1007/bfoo912721.

Rogers, C., \& Dymond, R. (1954). Pychotcrapy and personality chance. Chicago: University of Chicago Press.

Scott, W. (1968). Conceptions of normality" hand book of personality theory and research (pp. 974-1006). Chicago: Rand Mc Wally.

Selcuk, Z. (2000). Development and learning. Ankara: Nobel Yayın Dağıtım.

Shanahan, T. (1992). Reading comprehension as a conversation with an author. In: M. Presley, K. R. Harris \& J. T. Guthrie (Eds.), Promotion Academic Competence and Literacy in School. San Diego, CA: Academic Press.

Spence, D. J., Yore, L. D., \& Williams, R. L. (1999). The effects of explicit science reading instruction on selected grade 7 students' metacognition and comprehension of specific science text. Journal of Elementary Science Education, 11(2), 15-30. Available at: https://doi.org/10.1007/bfo3 173836 .

Sternberg, R. J. (1988). Intelligence applied. Orlando, FL: Harcourt Brace Jovanovich.

Tosun, A., \& Irak, M. (2008). Turkish adaptation, validity, reliability, anxiety and its relationship with obsessive-compulsive symptoms of metacognition scale-30. Turkish Journal of Psychiatry, 19(1), 67-80.

Wylie, R. (1961). The self concept. Lincoln: University of Nebraska Press. 